Pierik, R.L.M. and B.J. Ippel. 1977. Plantlet formation from excised bulb scale segments of Nerine. Acta Hort. 78:197-202.

Pierik, R.L.M. and A.J.M. Post. 1975. Rapid vegetative propagation of Hyacinths orientalism L. in vitro. Sci. Hort. 3:293-297.

Rost, T.L. and K. Paterson. 1976. The developmental anatomy of adventive plantlets from leaves and leaf segments of Crassula argentea
(Crassulaceae). Bet. Gaz. 137:203-210.

Van Aartrijk, J. and G.J. Blom-Barnhoorn. 1983. Adventitious bud formation from bulb-scale explants of Lillium speciosum Thunb. in vitro. Effect of wounding, TIBA, and temperature. $\mathrm{Z}$. Pflanzenphysiol. 110:355-363.

Van Aartrijk, J. and G.J. Blom-Barnhoorn. 1985. Adventitious bud formation from bulb-scale explants of Lilium speciosum Thunb. in vitro. Ef- fects of amino-ethoxyvinyl-glycine, 1aminocyclopropane-1-carboxylic acid, and ethylene. J. Plant Physiol. 117:401-410.

Van Rensburg, J.G.J. and J. Van Staden. 1988. Initiation of adventitious buds from Lachenalia leaf tissue in vitro. Proc. Annu. Congr. S. Afr. Assn. Bet. p. 83. (Abstr.)

Wright, N.A. and P.G. Alderson. 1980. The growth of tulip tissues in vitro. Acta Hort. 109:263270 .

\section{Micropropagation of the Aquatic Plant Cryptocoryne lucens}

\author{
Michael E. Kane, Edward F. Gilman, Matthew A. Jenks, and \\ Thomas J. Sheehan \\ Department of Environmental Horticulture, IFAS, University of Florida, \\ Gainesville, FL 32611
}

Additional index words. aquarium plant, in vitro culture, growth regulators, Araceae

Abstract. Procedures for in vitro establishment, rapid shoot proliferation, and ex vitro plantlet acclimatization of Cryptocoryne lucens de Witt were determined. Shoot cultures were established from surface-sterilized shoot tips cultured on Linsmaier and Skoog salts and vitamins medium (LS) solidified with $0.8 \%(\mathrm{w} / \mathrm{v})$ agar and supplemented with $2.0 \mu \mathrm{M}$ BA and $0.5 \mu \mathrm{M}$ NAA. The effect of BA (0 to $20 \mu \mathrm{M})$ and $0.5 \mu \mathrm{M}$ NAA on shoot multiplication from single-node and clustered triple-node shoot explants was determined after 35 days. The most efficient shoot proliferation ( 7.7 shoots/explant) occurred from single-node shoot explants cultured on LS + 20 $\mu \mathrm{M}$ BA and $0.5 \mu \mathrm{M}$ NAA. Maximum plantlet establishment was achieved by direct sticking of triple-node (cluster) microcuttings in either soilless planting medium or polyurethane foam cubes. Production of highly branched salable plants from microcuttings was possible within 18 weeks. Chemical names used: N-(phenylmethyl) -1H-purin-6-amine (BA); 1-naphthaleneacetic acid (NAA).

The genus Cryptocoryne (Araceae) contains some of the most commercially important ornamental aquatic species used in the aquarium plant trade (Rataj and Horeman, 1977). Most cryptocorynes are native to southeast Asia and Indonesia and grow either submersed or emersed. Seed production is rare and vegetative propagation by rhizome division is extremely slow (Windelov, 1987). Therefore, most Cryptocoryne spp. sold in the United States are collected from natural populations, imported, subdivided into unbranched plantlets, and maintained in holding tanks before sale. Unreliable supply from the export countries combined with frequent loss of plants to a poorly characterized leaf decomposition disease, commonly termed "cryptocoryne melt down" (D. Bryan, personal communication), have decreased the availability of quality plants. In vitro production of Cryptocoryne spp. could alleviate both problems of supply and quality.

Several studies have demonstrated that certain aquatic plants are amenable to in vi-

Received for publication 16 May 1989. Florida Agr. Expt. Sta. J. Ser. no. 9950. Funded in part through the IFAS Center for Natural Resources. The cost of publishing this paper was defrayed in part by the payment of page charges. Under postal regulations, this paper therefore must be hereby marked advertisement solely to indicate this fact. tro propagation either by proliferation from pre-existing buds (Harder. 1968: Kane et al.. 1988b; Uma and Mohan Ram, 1972) or through adventitious shoot formation (Kane et al., 1988a; Kane and Albert, 1989; Rao

Table 1. Effect of BA on mean shoot multiplication of Cryptocoryne lucens from single- and triplenode explants cultured for 35 days.

\begin{tabular}{|c|c|c|c|c|c|c|}
\hline \multirow[b]{2}{*}{ Explant } & \multicolumn{6}{|c|}{$\mathrm{BA}(\mu \mathrm{M})$} \\
\hline & $\theta$ & 0.5 & 2.5 & 5 & 10 & 20 \\
\hline $\begin{array}{l}\text { Single-node } \\
\text { Triple-node }\end{array}$ & $\begin{array}{c}4.0 \\
8.8(2.9)\end{array}$ & $\begin{array}{c}4.5 \\
8.0(2.7)\end{array}$ & $\begin{array}{c}\text { Shoots p } \\
5.4 \\
10.3(3.4)\end{array}$ & $\begin{array}{c}\text { tuced (no.) } \\
5.4 \\
12.8(4.3)\end{array}$ & $\begin{array}{c}5.6 \\
11.5(3.0)\end{array}$ & $\begin{array}{r}7.7 \\
13.4(4.5)\end{array}$ \\
\hline Source of variation & & $\mathrm{df}$ & MS & $\mathrm{F}$ & Prob $>F$ & \\
\hline $\begin{array}{l}\text { Explant }(\mathrm{E}) \\
\text { Concentration }(\mathrm{C}) \\
\text { ExC } \\
\text { Error }\end{array}$ & & $\begin{array}{r}1 \\
5 \\
5 \\
283\end{array}$ & $\begin{array}{c}2111.84 \\
134.53 \\
20.67 \\
6.9\end{array}$ & $\begin{array}{r}305.50 \\
19.46 \\
2.99\end{array}$ & $\begin{array}{r}<0.001 \\
<0.001 \\
0.012\end{array}$ & \\
\hline
\end{tabular}

${ }^{2}$ Values in parenthesis represent mean number of shoots produced per explant node.

Table 2. Post-transplant survival and branching of single- and triple-node microcuttings 6fryptocoryne lucens after 18 weeks.

\begin{tabular}{|c|c|c|c|c|c|}
\hline \multirow{2}{*}{$\begin{array}{l}\text { Planting } \\
\text { medium }\end{array}$} & \multirow[b]{2}{*}{$\mathrm{N}$} & \multicolumn{2}{|c|}{ Microcutting survival (\%) } & \multicolumn{2}{|c|}{ No. branches/microcutting type } \\
\hline & & Single-node & Triple-node & Single-node & Triple-node \\
\hline $\begin{array}{l}\text { Polyurethane foam } \\
\text { cubes }\end{array}$ & 144 & 69.9 & 99.3 & 3.8 & 11.9 \\
\hline \multicolumn{6}{|l|}{ Vergro } \\
\hline 4-cell pack & 48 & 45.8 & 91.7 & 5.3 & 11.9 \\
\hline 12-cell pack & 48 & 97.9 & 100 & 7.2 & 11.0 \\
\hline Tukey's HSD (0.05) & & & & \multicolumn{2}{|c|}{3.1} \\
\hline
\end{tabular}




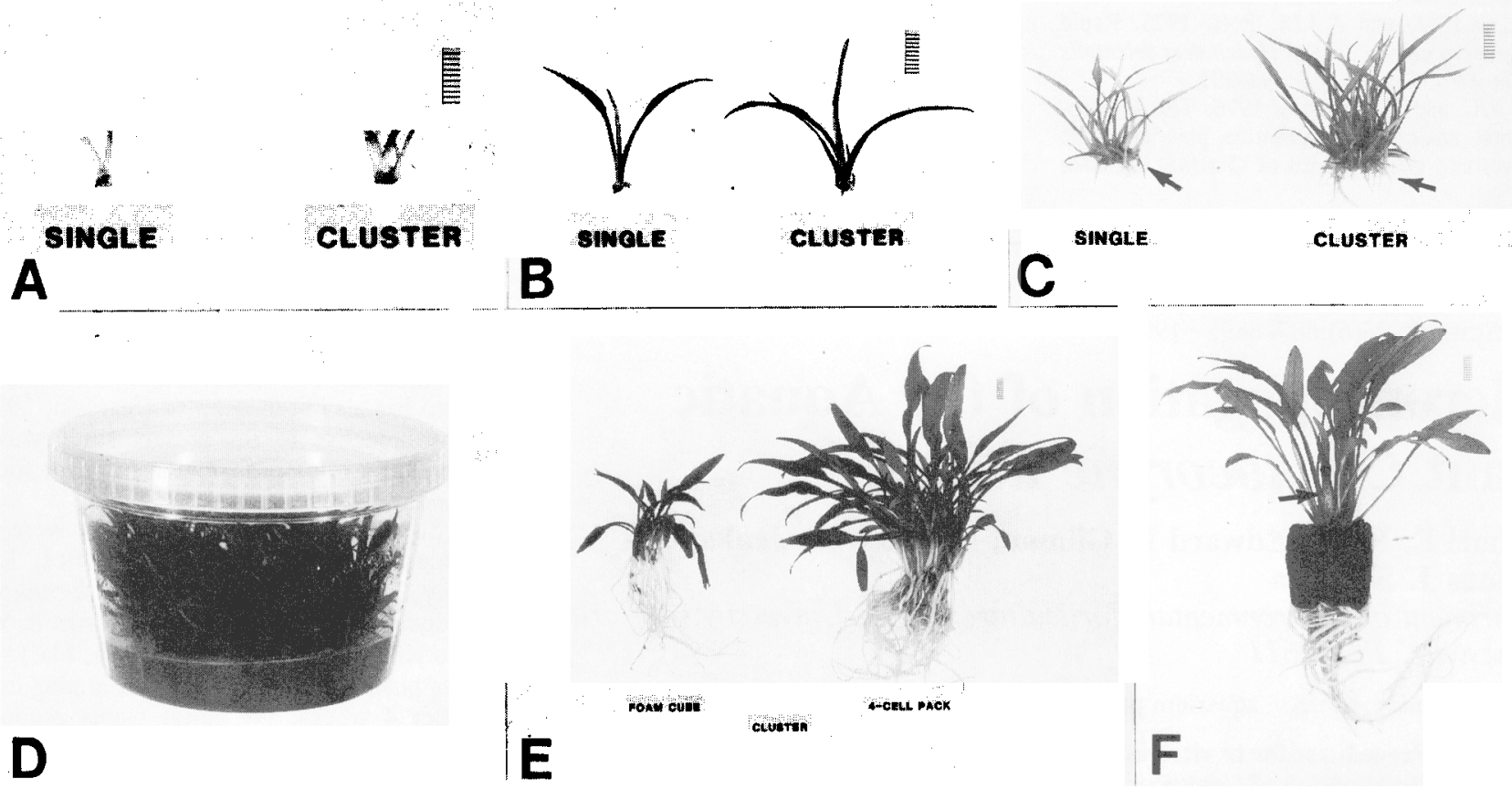

Fig. 1. (A) Single- and triple-node (cluster) shoot explants of Cryptocoryne lucens. (B) Single- and triple-node microcuttings. (C) Shoot multiplication from single- and triple-node (cluster) explants cultured on LS plus $20 \mu \mathrm{M}$ BA for 35 days. Note presence of roots (arrows). (D) Multiple shoot formation from single-node shoot explants after 35 days of culture on LS plus $20 \mu \mathrm{M}$ BA. (E) Comparative rooting. branching, and leaf development of triple-node (cluster) microcuttings grown aerially for 18 weeks in polyurethane foam cubes and four-cell packs containing Vergro (F) Flowering (arrow) of established in vitro-derived plant 30 weeks post-transplant.

dium $\mathrm{pH}$ was adjusted to 5.7 with $0.1 \mathrm{~N} \mathrm{KOH}$ before addition of agar and autoclaving at $1.2 \mathrm{~kg} \cdot \mathrm{cm}^{-2}$ for $20 \mathrm{~min}$ at $121 \mathrm{C}$. Cultures were maintained in incubators at $25 \pm 1 \mathrm{C}$ under a 16-hr photoperiod provided by coolwhite fluorescent lamps (General Electric F20T12-CW) at $40 \mu \mathrm{mol} \cdot \mathrm{s}^{-1} \cdot \mathrm{m}^{-2}$ measured at culture level. Stock cultures were divided and subculture at 4-week intervals.

Using single- and triple-node (cluster) shoot explants (Fig. 1A) from stock cultures, shoot multiplication was evaluated after 35 days culture in 473-ml clear polypropylene culture vessels (Better Plastics, Kissimmee, Fla.) each containing $100 \mathrm{ml}$ of agar-solidified $(0.8 \% \mathrm{w} / \mathrm{v})$ LS supplemented with BA (0 to $20 \mu \mathrm{M})$ and $0.5 \mu \mathrm{M}$ NAA. The basal end of each explant was inserted $\approx 3 \mathrm{~mm}$ into the medium. A completely randomized design was used with five explants per vessel replicated five times. Data were tested by analysis of variance with mean separation by Tukey's HSD (SAS Institute, 1985).

Rooting and establishment of single- and triple-node microcuttings (Fig. 1B) were evaluated in plastic bedding plant flats containing either $3.5 \times 3.5 \times 3.5-\mathrm{cm}$ polyurethane foam cubes (LC-1 Horticube growing medium; Smithers-Oasis, Kent, Ohio) or fourcell $(6.1 \times 3.8 \times 6.0$-cm cells $)$ and 12-cell $(4.6 \times 3.5 \times 6.0-\mathrm{cm}$ cells $)$ packs containing Vergro Klay Mix A. Planting media were saturated weekly with $20 \mathrm{~N}-13.9 \mathrm{P}-3.7 \mathrm{~K}$ liquid fertilizer containing $150 \mathrm{mg} \mathrm{N} / \mathrm{liter}$ and each tray was covered with a clear vinyl propagation dome to maintain high humidity. On 1 Sept. 1988, microcuttings were planted and maintained at $25 \pm 3 \mathrm{C}$ under a 16-hr photoperiod (cool-white fluorescent lamps) at $70 \mu \mathrm{mol} \cdot \mathrm{s}^{-1} \cdot \mathrm{m}^{-2}$. After 3 weeks, the propagation domes were removed over 5 days to gradually decrease humidity and acclimatize the plantlets. Trays were transferred to a lightly shaded greenhouse (950 to $1160 \mu \mathrm{mol} \cdot \mathrm{s}^{-1} \cdot \mathrm{m}^{-2}$ ) with temperature set points for heating and cooling at 18/29C, respectively. Plantlet establishment was evaluated 18 weeks post-transplant.

Shoot proliferation from both single and clustered triple-node shoot explants of $C$. $l u$ cens was significantly enhanced by the addition of BA (Table 1). Maximum shoot proliferation from both explant types was observed on LS plus $20 \mu \mathrm{m}$ BA. At $40 \mu \mathrm{M}$ $\mathrm{BA}$, severe leaf chlorosis and a reduction in shoot multiplication occurred. Total number of shoots produced per explant was significantly greater from triple-node (cluster) explants (Fig. 1C). However, no proliferation benefit was observed from the use of triplenode explants since their mean number of shoots produced per explant node was significantly lower than that for single-node explants. All shoots on BA-supplemented media rooted and developed dark green leaves with red margins and petioles (Fig. 1C). Starting with 20 single-node explants per culture vessel, an' average production of $\approx 150$ singlenode microcuttings per culture vessel can be generated per 35-day culture cycle on LS plus $20 \mu \mathrm{M}$ BA and $0.5 \mu \mathrm{M}$ NAA (Fig. 1D).

Post-transplant survival of single-node microcuttings was lower than that of triplenode microcuttings in the planting media tested (Table 2). Regardless of planting medium or cell pack size, survival of triple- node microcuttings exceeded $91 \%$ (Table 2). Microcutting mortality generally occurred during the first 2 weeks post-transplant. All surviving microcuttings developed extensive root systems (Fig. 1E). Post-transplant basal branching of all triple-node microcuttings was significantly greater than single-node microcuttings (Table 2). There were no differences in post-transplant branching between triplenode microcuttings established in either the foam cubes or cell packs. Although not enumerated, plants grown in four-cell packs produced more large leaves resulting in higher quality plants within 15 weeks (Fig. 1E). Flowering of plants established from microcuttings occurred 30 weeks post-transplant (Fig. IF).

Several benefits are apparent from the in vitro propagation of cryptocorynes. Unlike plants collected from natural populations, cryptocorynes produced in vitro are highly branched. Aerial culture of in vitro-derived microcuttings in plug trays eliminates both stock plant lost to leaf decomposition disease and algal growth problems frequently encountered in tank cultures. Consequently, in vitro propagation of cryptocorynes provides a method to rapidly produce salable plants of superior quality.

\section{Literature Cited}

Harder, R. 1968. Axenische kultur von Aponogeton distachyus L. Planta 82:193-199.

Kane, M. E., D.B. McConnell, T.J. Sheehan, and B. Dehgan. 1988a. A laboratory exercise to demonstrate adventitious shoot formation using stem internodes of Parrot-feather. HortScience 23:408. 
Kane, M. E., T.J. Sheehan, and F.H. Ferwerda. 1988b. In vitro growth of American Lotus embryos. HortScience 23:611-613.

Kane, M.E. and L.S. Albert. 1989. Comparative shoot and root regeneration from juvenile and adult aerial leaf explants of Variable-leaf Milfoil. J. Aquatic Plant Mgt. 27:1-10.

Linsmaier, E.M. and F. Skoog. 1965. Organic growth factor requirements of tobacco tissue cultures. Physiol. Plant. 18:100-127.

Rao, S. and H.Y. Mohan Ram. 1981. Regeneration of whole plants from cultured root tips of Limnophila indica. Can. J. Bet. 59:969-973.

Rataj, R. and T.J. Horeman. 1977. Aquarium plants. T. F. H., Neptune City, N.J.

SAS Institute, Inc. 1985. SAS user's guide: Sta- tistics. SAS Institute, Inc., Cary, N.C

Staritski, G. 1977. Die vitrokultur von Cryptocoryne. Aqua-Planta 1:3-6.

Urea, M.C. and H.Y. Mohan Ram. 1972. In vitro culture of Vallisneria spiralis. Phytomorphology 22:121-124.

Windelov, H. 1987. Aquarium plants. T.F.H Neptune City, N.J.

\section{Floral Supplier Service Levels to Retail Florist and Mass Market Customers}

\author{
Thomas L. Prince ${ }^{1}$, Harry K. Tayama ${ }^{2}$, and John R. Grabner, Jr. ${ }^{3}$ \\ Department of Horticulture, Ohio Agricultural Research and \\ Development Center, The Ohio State University, Columbus, OH 43210
}

Additional index word. flower, marketing, distribution channel, survey

\begin{abstract}
A survey analysis of retail florists in the Midwestern United States and floral mass marketers, nationally, profiled the level of service provided by their primary floral suppliers on 10 service characteristics. There is substantial variability in service levels provided to retail florists and mass marketers by suppliers. The greatest variability in service levels was for services relative to maintenance of product quality, product availability, communications/order information, product discounts, and product labeling. Retail florists perceived higher levels of service relative to delivery speed and order/delivery reliability than mass marketers. Mass marketers perceived higher levels of service from suppliers relative to communications/order information and product labeling, compared to retail florists. The service profiles provide floral suppliers management information for the development of service programs targeted for specific customer segments.
\end{abstract}

In the highly competitive and international business climate of the floriculture industry, managers have realized the importance of improving product quality to remain competitive. However, as the U.S. economy evolves from a production orientation to one of service (Cowell, 1984), management of many businesses is viewing improvements to service as a competitive strategy in the global marketplace (Peters and Waterman, 1982; Garvin, 1983; Takeuchi and Quelch, 1983; Heskett, 1987; Lalonde et al., 1988).

A method of incorporating service as a strategic element within a business enterprise is for management to plan and develop a

Received for publication 3 Apr. 1989. From a dissertation submitted by T.L.P. in partial fulfillment of the requirements for the $\mathrm{PhD}$. Salaries and research support provided by State and Federal Funds appropriated to the Ohio Agricultural Research and Development Center, The Ohio State Univ. Approved for publication as manuscript no. 67-89 of the Ohio Agricultural Research and Development Center, Wooster, OH 44691. The cost of publishing this paper was defrayed in part by the payment of page charges. Under postal regulations, this paper therefore must be hereby marked advertisement solely to indicate this fact.

'Postdoctoral Fellow.

${ }^{2}$ Professor of Horticulture.

${ }^{3}$ Associate Professor, Faculty of Marketing, College of Business, The Ohio State Univ., 1775 College Rd., Columbus, OH 43210. customer service program (Heskett, 1971; Prince et al., 1989). Customer service comprises, in addition to the product, activities and performances provided by a supplier to a customer, with the purpose of gaining repeat sales (Hopkins and Bailey, 1970). Customer service forms the interface between sellers and buyers in the distribution channel and forms the basis for market transactions and distribution strategy (LaLonde, 1985). In the floriculture industry, services are important, as they comprise a major share of supplier maintenance of product quality. marketers using $x^{2}$ test. the costs of marketing floral products (Goodrich, 1980; Sullivan et al., 1980).

For floral suppliers to derive the benefits of customer service, information relative to the levels of service currently provided by suppliers to their customers is needed. Development of this management information would provide floral suppliers with benchmark statistics relative to the competitive service levels within the industry. Furthermore, such industry statistics could be used by suppliers to develop target service levels or service standards when implementing a customer service program.

The survey. The research methodology was conducted as described by Prince (1989). Perceptions of suppliers' service performance were obtained from the buyers' perspective (retail florists and mass marketers), as advocated by LaLonde et al. (1988). The retail florist population comprised full-service florist shops in the states of Ohio, Indiana, Illinois, Michigan, Minnesota, Wisconsin, Iowa, Missouri, North Dakota, South Dakota, Nebraska, and Kansas. The mass-market population included supermarket chains, both cooperative organizations and independent food grocers, and nonfood mass merchandisers throughout the United States.

A random sample of firms from each population was selected and mailed questionnaires relative to services provided by suppliers. The floral buyer of each firm rated its primary supplier on the level of service provided for 10 service characteristics: supplier maintenance of product quality, order/ delivery reliability, delivery speed, product availability, order/delivery flexibility, response to problems, accessibility, commu-

Table 1. Distribution of retail florists (RF) and mass marketers (MM) reporting service levels for

\begin{tabular}{|c|c|c|c|c|c|c|}
\hline \multirow[b]{2}{*}{ Question description } & \multirow[b]{2}{*}{ Sample } & \multicolumn{5}{|c|}{ Service levels ${ }^{z, y}$} \\
\hline & & Under $80 \%$ & $80 \%-89 \%$ & $90 \%-94 \%$ & $95 \%-99 \%$ & $100 \%$ \\
\hline $\begin{array}{l}\text { Deliveries filled with } \\
\text { the quality of floral } \\
\text { product expected }\end{array}$ & $\begin{array}{l}\mathrm{RF} \\
\mathrm{MM}\end{array}$ & $\begin{array}{l}19 \\
16\end{array}$ & $\begin{array}{l}\text { Percent } \\
11 \\
8\end{array}$ & $\begin{array}{l}\text { age of firm } \\
28 \\
21\end{array}$ & $\begin{array}{l}39 \\
52\end{array}$ & $\begin{array}{l}3 \\
3\end{array}$ \\
\hline $\begin{array}{l}\text { Deliveries without } \\
\text { damage due to improper } \\
\text { packaging or shipping }\end{array}$ & $\begin{array}{l}\mathrm{RF} \\
\mathrm{MM}\end{array}$ & $\begin{array}{l}14 \\
13\end{array}$ & $\begin{array}{l}3 \\
5\end{array}$ & $\begin{array}{l}11 \\
11\end{array}$ & $\begin{array}{c}=0.57 \\
55 \\
50\end{array}$ & $\begin{array}{l}17 \\
21\end{array}$ \\
\hline $\begin{array}{l}\text { Floral product purchases } \\
\text { that are suitable for use }\end{array}$ & $\begin{array}{l}\mathrm{RF} \\
\mathrm{MM}\end{array}$ & $\begin{array}{l}12 \\
13\end{array}$ & $\begin{array}{l}2 \\
3\end{array}$ & $\begin{array}{r}11 \\
3\end{array}$ & $\begin{array}{c}=0.93 \\
65 \\
55 \\
=0.02\end{array}$ & $\begin{array}{l}10 \\
26\end{array}$ \\
\hline
\end{tabular}

${ }^{2}$ Seven-point scale collapsed into five categories; RF, $\mathrm{n}=502 ; \mathrm{MM}, \mathrm{n}=38$.

${ }^{\prime} P$ indicates significance of differences in percentage distributions between retail florists and mass 